\title{
An examination of variable growth in the loliginid squid Sepioteuthis lessoniana: a whole animal and reductionist approach
}

\author{
Jayson M. Semmens $^{1, *}$, Natalie A. Moltschaniwskyj ${ }^{1,2}$ \\ ${ }^{1}$ School of Marine Biology and Aquaculture, James Cook University, Townsville, Queensland 4811, Australia \\ ${ }^{2}$ School of Aquaculture, University of Tasmania, PO Box 1214, Launceston, Tasmania 7250, Australia
}

\begin{abstract}
Squids typically demonstrate considerable plasticity in individual growth rates. However, it is not known if individuals growing at different rates also differ at lower levels of organisation. We wished to determine if Sepioteuthis lessoniana individuals that were larger than predicted for their age differed in their digestive gland and mantle muscle tissue proximal composition or mantle muscle structure, compared with individuals that were smaller for their age than predicted. The residual, the difference between the observed size-at-age and that predicted by the growth equation, was used as a measure of the difference in an individual's lifetime growth from the population average. Individual squid varied considerably in their size-at-age, with juveniles showing less variation than adults. Juveniles had greater concentrations of lipid in their muscle tissue, perhaps due to an emphasis on storing energy reserves in this critical period of their life. Differences in biochemical constituents in both the digestive gland and muscle tissue were not related to the size-at-age of individuals, despite biochemical make-up being the lowest organisational level of growth. This may be due to whole animal growth and changes in biochemical composition occurring on different time scales. There was no relationship between the size-at-age of individuals and average mantle muscle fibre size. A strong relationship. however, existed between the size of mantle muscle blocks and the size-at-age of individuals for both juvenile and adult individuals, suggesting that larger muscle blocks are related to both body size and faster individual growth rates. This study demonstrates a clear relationship between mantle muscle structure and growth and the size-at-age of $S$. lessoniana individuals.
\end{abstract}

KEY WORDS: Squid $\cdot$ Size-at-age $\cdot$ Condition $\cdot$ Muscle tissue $\cdot$ Digestive gland

\section{INTRODUCTION}

Plasticity in loliginid squid growth is evident in both the variability in individual growth rates (e.g. Natsukari et al. 1988, Jackson et al. 1997) and the variability in size and age at maturity (e.g. Arkhipkin \& Nekludova 1993, Jackson \& Yeatman 1996). These plastic growth responses may be influenced by such factors as temperature (Jackson et al. 1997), prey availability (O'Dor et al. 1980), population density (Dawe 1988), sexual maturation (Brodziak \& Macy 1996) and sex-specific growth rates (Rodhouse \& Hatfield 1990).

\footnotetext{
•E-mail: jayson semmens@jcu.edu.au
}

However, we do not know how these differences in growth rates between individuals are reflected in the composition and structure of organs such as the muscle tissue or digestive gland. This research examines the question of whether individuals that are large for their age differ in their biochemical composition and structural organisation, when compared to those individuals that are small for their age.

Cephalopods are characterised by rapid constant indeterminate growth throughout their life, with no asymptotic size limits being approached (Alford \& Jackson 1993). Recent age and growth studies, using daily statolith increments to determine age, and length as a measure of size, show that both exponential and linear growth patterns are common for squid (exponential: e.g. Bigelow 1994, Brodziak \& Macy 1996; linear: e.g. 
Jackson 1990, Rodhouse \& Hatfield 1990, Jackson \& Choat 1992). The overall growth rates of squid exceed those of fish because growth continues during the adult phase (Moltschaniwskyj 1994). Some squid species display 2 distinct phases of growth. Initially juveniles grow exponentially, followed by a logarithmic adult growth phase (e.g. Nigmatullin et al. 1995).

Patterns of growth at the whole animal level are reflected at any of a series of lower levels of biological organization such as: relative growth of organs and tissues, growth dynamics of tissues, and the relative concentration of the biochemical constituents of tissues and organs (Weatherley 1990). The measurement of these various lower levels of biological organization is used to assess the condition or health of an individual and can play an important role in understanding the observed plasticity of life-history traits (Ferron \& Leggett 1994).

Examination of mantle muscle tissue of cephalopods has allowed us to understand the relative importance of fibre production and fibre growth to whole animal growth as cephalopods increase in size (Moltschaniwskyj 1994, Pecl \& Moltschaniwskyj 1997, Preuss et al. 1997). It has also been used as a tool to understand differences in growth at different food levels and temperatures (Moltschaniwskyj \& Martinez 1998). However, we have not yet examined how the relative rates of hyperplasia (new fibre generation) and hypertrophy (growth of existing fibres) differ among wild individuals growing at different rates

With both the mantle muscle and digestive gland tissue proposed as energy storage substrates and sites in cephalopods, proximal analysis of the biochemical constituents of these tissues has been used to examine the dynamics of squid growth, reproduction and energy storage at a population level (e.g. Clarke et al. 1994). However, there has been little attempt to examine condition at the individual level and relate this to their growth, as has been done with fish (Weatherley 1990). This may prove to be an approach which yields important information about the plastic growth of squids, by determining what changes at different levels of organization reflect a fast-or slow-growing individual.

The aim of this study was to determine if individuals that differed in size-at-age at the whole animal level also differed at lower levels of organisation. In particular, differences in the structure of the mantle muscle and the biochemical composition of the muscle and digestive gland of individuals of Sepioteuthis lessoniana were examined.

\section{MATERIALS AND METHODS}

Specimen collection. A total of 107 individuals of Sepioteuthis lessoniana were collected from waters around Townsville, Australia $\left(19^{\circ} 15^{\prime} \mathrm{S}, 146^{\circ} 50^{\prime} \mathrm{E}\right)$ Twenty-nine juvenile $S$. lessoniana individuals ranging from 16.7 to $43.1 \mathrm{~mm}$ dorsal mantle length (ML) were collected with dip and purse seine nets in the Townsville region, over a $5 \mathrm{~d}$ period in January 1995. Seventy-eight 'adults' (82.3 to $244.8 \mathrm{~mm} \mathrm{ML)} \mathrm{were}$ captured using 'squid jigs' in the Townsville region. Of these adult $S$. lessoniana individuals, 40 were captured between January and March 1995, 27 between June and August 1995 and 11 between April and June 1996.

The ML of each individual was measured and adults were sexed and assigned a reproductive maturity status, either 1 to 3 (immature) or 4 and 5 (mature) based on the Lipinski scale (Lipinski 1979). Samples of the digestive gland and mantle muscle from each individual were retained and frozen for biochemical analysis. Muscle samples of 36 adult and 18 juvenile individuals were taken from the dorsal side of the anterior mantle at a point level with the cartilaginous mantle locking mechanism, and fixed in a formalin-acetic acid-calcium chloride (FAACC) solution for $48 \mathrm{~h}$ in preparation for histological analysis.

Size-at-age. Estimates of growth for individuals were obtained using size-at-age information. Age estimates were made from counts of daily increments in statoliths viewed using a light microscope. The statoliths of squid, like the otoliths of fish, can be used to provide accurate age estimates (Jackson 1994). For 51 adults (27 were captured between January and March 1995 and 24 between June and July 1995) and 19 juveniles, each pair of statoliths were extracted from the squid and stored in $70 \%$ ethanol. All statoliths were cleaned and dried before being prepared for reading growth increments. Statoliths were prepared and their increments counted following the methodology of Jackson (1990). The increments in the statoliths of individuals of Sepioteuthis lessoniana have been validated as daily growth increments (Jackson 1990). All increment counts were made in the dorsal-dome region of the statolith, as increment definition was consistently clearest here. Increment counts were repeated 3 times for each individual and, providing the counts did not differ from each other by more than $10 \%$, an average of the 3 counts was used

Biochemical processing. Digestive gland and mantle muscle samples were weighed before and after freeze drying to calculate water content. Tissue was then homogenised in $5 \mathrm{ml}$ of $100 \mathrm{mM} \mathrm{NaCl}$ solution. Concentrations of each compositional element were quantified colourmetrically and read using a spectrophotometer at the appropriate wavelength. For all proximal analyses, duplicates were run for each individual squid. Carbohydrate concentration in the muscle tissue and digestive gland was determined using a modification of the methodology of Mann \& Gallager 
(1985). The absorbency was recorded and converted to $\mu \mathrm{g}$ of carbohydrate via a standard curve constructed using D-glucose. Lipid concentration was determined by a chloroform/methanol extraction (Mann \& Gallager 1985). Absorbance was converted to $\mu \mathrm{g}$ of lipid via a standard curve constructed using tripalmitin. Protein content was estimated using the method of Bradford (1976). Absorbance was converted to mg of protein via a standard curve constructed using bovine serum albumin. The concentrations of the compositional elements were expressed as a percentage of the total mantle muscle and digestive gland wet weights.

Histological processing. Muscle tissue fixed in FAACC was transferred to $70 \%$ ethanol for $24 \mathrm{~h}$. Tissue was then dehydrated in a graded ethanol series, cleared in toluene, infiltrated and impregnated with paraffin wax. Sections were cut at $6 \mu \mathrm{m}$, stained with Mallory-Heidenhain and mounted on slides with dibutylphthalate-polystyrene-xylene (DPX).

Circular muscle fibres, which are orientated around the body in the mantle tissue, are divided into blocks by radial muscle fibres. The widths of these blocks were used as an assessment of growth. From each individual 10 randomly chosen muscle blocks were measured. As each block measured cannot be considered as an independent replicate, but an individual squid can, the average block size for each individual was used in the analysis.

The fibre density within a muscle block provides information about the generation of new fibres and the growth of existing fibres. The diameter of 30 randomly chosen fibres from within 3 randomly chosen muscle blocks was measured. The mean diameter of the 30 fibres was calculated for each individual, again providing a description of the individual.

Statistical analysis. Individuals were defined as large for their age or small for their age relative to one another by examining the size-at-age relationship. A discontinuity was apparent between juveniles (16.7 to $43.1 \mathrm{~mm} \mathrm{ML}, 17$ to $63 \mathrm{~d}$ ) and adults (82.3 to $238.3 \mathrm{~mm}$ ML, 71 to 187 d). Therefore, the 51 adults and 19 juveniles were treated separately and a linear growth function fitted for each group. A linear growth function was also fitted for both males and females, with immature and mature individuals also plotted separately to determine if either sex and/or sexual maturity were influencing the size-at-age relationship. The residual, the difference between the observed size-at-age and that predicted by the linear equation, was used as a relative measure of growth among the individuals. Residuals were standardised to a mean of 0 and a standard deviation of 1, eliminating the effect of body size and allowing adults and juveniles to be compared. Individuals with positive residuals were larger for their age than the population average, and those individuals

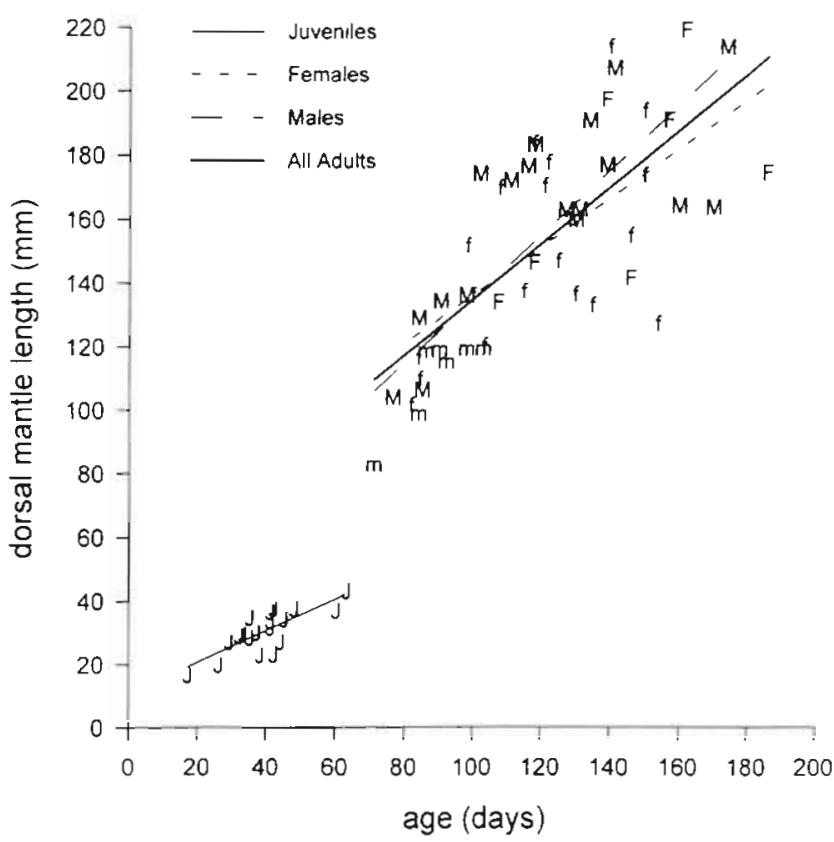

Fig. 1 Sepioteuthis lessoniana. Size-at-age relationships for adult and juvenile individuals. Linear regression lines are given for juveniles, females, males and all adults combined. J: Juvenile; f: immature females; F: mature females; $\mathrm{m}$ : immature males; $\mathrm{M}$ : mature males

with negative residuals were smaller for their age than the population average

Pearson correlation coefficients were used to determine the association between proximal elements of muscle tissue and the digestive gland and the residuals from the size-at-age relationships. Correlations between the residuals and the muscle block size and fibre width were also examined. As there was no difference between the size-at-age relationships for males and females or those for maturity status (Fig. 1), a single regression line was fitted to all these individuals. The concentrations of the compositional elements for both the digestive gland and the mantle muscle were compared between adults and juveniles using $t$-tests.

\section{RESULTS}

\section{Growth}

Individual squid varied considerably in their size-atage. However, males and females demonstrated similar growth, as did immature and mature individuals (Fig. 1). Juveniles demonstrated less variability in sizeat-age than did adults, with $61 \%$ of the variability in size explained by age for the juveniles (slope $=0.49 \pm$ 
Table 1. Sepioteuthis lessoniana. Proximal composition of mantle muscle tissue and digestive gland (mean \pm SE). $t$-tests were used to compare concentrations of different elements between adults and juveniles. ( $p$-value significant if $p<0.05$ )

\begin{tabular}{|c|c|c|c|c|c|c|}
\hline Element & Adult & Juvenile & All & $t$ & df & $\mathrm{p}$ \\
\hline \multicolumn{7}{|l|}{ Mantle muscle } \\
\hline Water & $74.08 \pm 0.32$ & $71.62 \pm 1.36$ & $73.32 \pm 0.49$ & -1.76 & 30 & 0.088 \\
\hline Protein & $6.12 \pm 0.37$ & $4.81 \pm 0.37$ & $5.72 \pm 0.29$ & -2.52 & 76 & 0.014 \\
\hline Carbohydrate & $0.46 \pm 0.02$ & $0.51 \pm 0.04$ & $0.47 \pm 0.02$ & 1.42 & 89 & 0.159 \\
\hline Lipid & $2.24 \pm 0.16$ & $3.11 \pm 0.21$ & $2.50 \pm 0.13$ & 3.17 & 88 & 0.002 \\
\hline \multicolumn{7}{|c|}{ Digestive gland } \\
\hline Water & $68.19 \pm 0.64$ & $67.86 \pm 2.79$ & $68.13 \pm 0.72$ & -0.18 & 74 & 0.859 \\
\hline Protein & $3.03 \pm 0.17$ & $4.05 \pm 0.63$ & $3.22 \pm 0.19$ & 1.55 & 15 & 0.141 \\
\hline Carbohydrate & $1.82 \pm 0.23$ & $2.11 \pm 0.41$ & $1.86 \pm 0.20$ & 0.54 & 71 & 0.592 \\
\hline Lipid & $10.23 \pm 0.68$ & $10.11 \pm 1.29$ & $10.21 \pm 0.60$ & -0.07 & 66 & 0.946 \\
\hline
\end{tabular}

$\left.0.10 \mathrm{SE}, \mathrm{r}^{2}=0.61, \mathrm{n}=19\right)$ and only $54 \%$ for the adults (slope $=0.88 \pm 0.11 \mathrm{SE}, \mathrm{r}^{2}=0.54, \mathrm{n}=51$ ).

\section{Proximal analysis}

The mantle muscle of individuals of Sepioteuthis lessoniana was predominantly comprised of water and to a lesser extent protein, with relatively low concentrations of lipid and carbohydrate (Table 1). Juveniles differed from adults in that they had greater concentrations of lipid (28\% greater) and lower concentrations of protein ( $21 \%$ less) in their muscle tissue.

Correlations between the residuals from the lengthage regression and the concentrations of the proximal elements for the mantle muscle were all relatively weak. Adults with larger sizes for their age than the average had less water in their muscle tissue than those with smaller sizes for their age $(r=-0.319, n=45$, $p=0.033$ ) (Fig. 2)

The digestive gland was also comprised predominantly of water; however lipid and carbohydrate were present in concentrations approximately $75 \%$ higher than those observed in muscle tissue. In contrast, protein and water concentrations were approximately 50 and $8 \%$ lower in the digestive gland of adults, respectively, compared with the muscle tissue. Juveniles, however, had similar levels of protein and water in both their digestive gland and muscle (Table 1). Unlike muscle tissue, the digestive glands of adult and juvenile Sepioteuthis lessoniana individuals were not significantly different in their concentration of the compositional elements.

Correlations between the residuals from the size-atage regression and the compositional elements in the digestive gland, like those of the muscle, were all relatively weak. Adults that were larger for their age than the average had digestive glands with less water ( $\mathrm{I}=$ $-0.374, n=42, p=0.015$ ) (Fig. 3A) and more lipid ( $\mathrm{r}=$

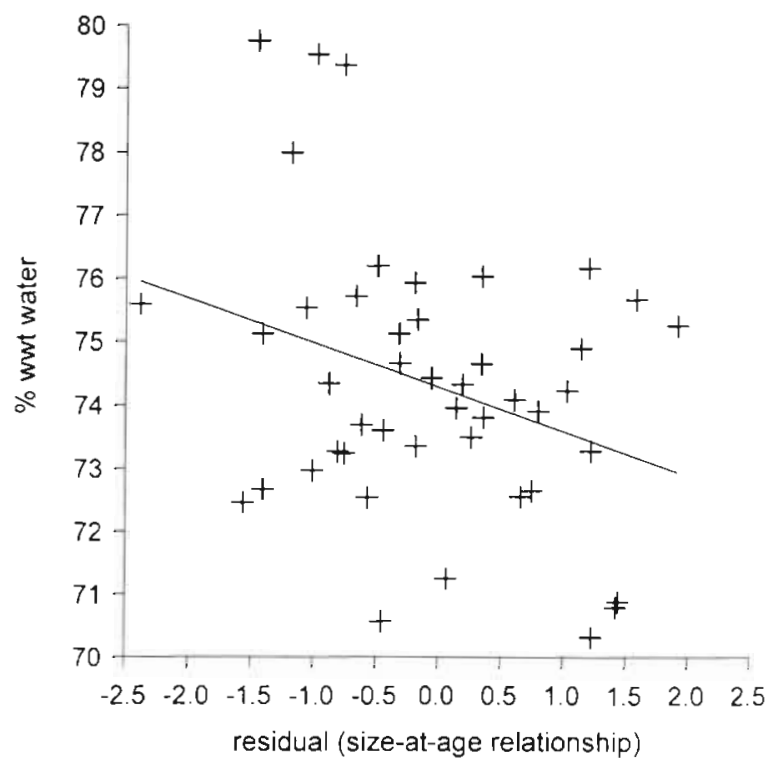

Fig. 2. Sepioteuthis lessoniana. Relationship between percent wet weight (\% wwt) water in the muscle tissue of adult individuals and the residuals from the size-at-age relationship. The linear regression line is given

0.493, $n=40, p=0.001$ ) (Fig. 3B) compared to those individuals that were smaller for their age than the average.

\section{Muscle tissue}

Individuals that were larger for their age than the average, both adults and juveniles, had significantly larger muscle blocks than their smaller for their age counterparts $\left(r_{\text {adults }}=0.684, \mathrm{n}=35, \mathrm{p}<0.001 ; \mathrm{r}_{\text {juveniles }}=\right.$ $0.698, n=17, p=0.002$ ) (Figs. $4 \&$ 5). However, there was no relationship between growth and fibre size for adults or juveniles. 

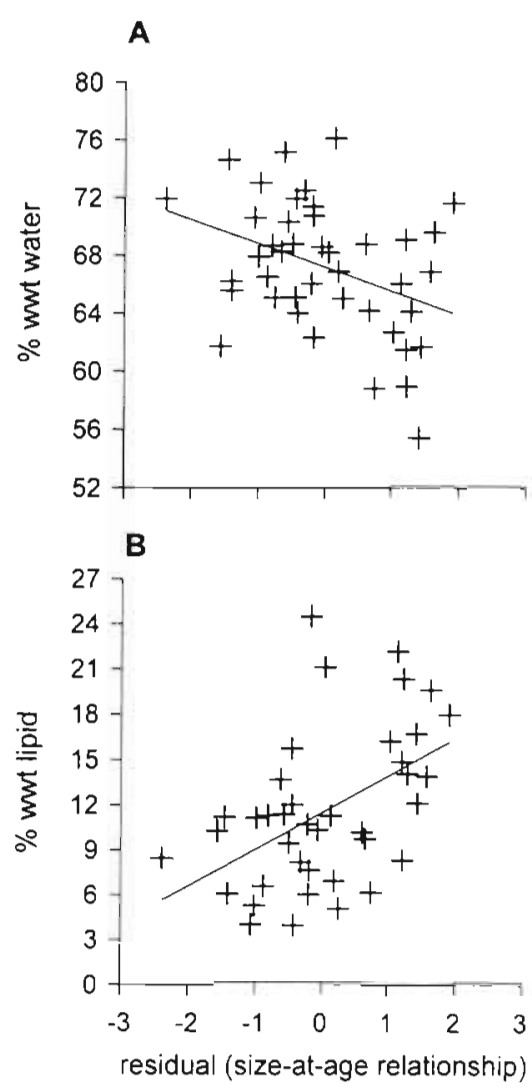

Fig. 3. Sepioteuthis lessoniana. Relationship between percent wet weight (\% wwt) (A) water and (B) lipid in the digestive gland tissue of adult individuals and the residuals from the size-at-age relationship. The linear regression line is given

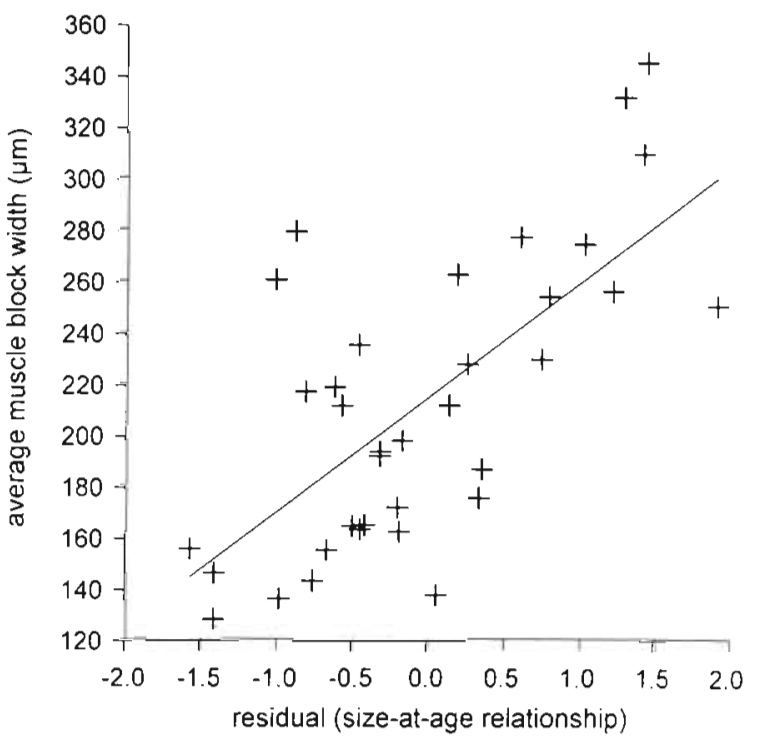

Fig. 4. Sepioteuthis lessoniana. Relationship between average muscle block width $(\mu \mathrm{m})$ of adult individuals and the residuals from the size-at-age relationship. The linear regression line is given

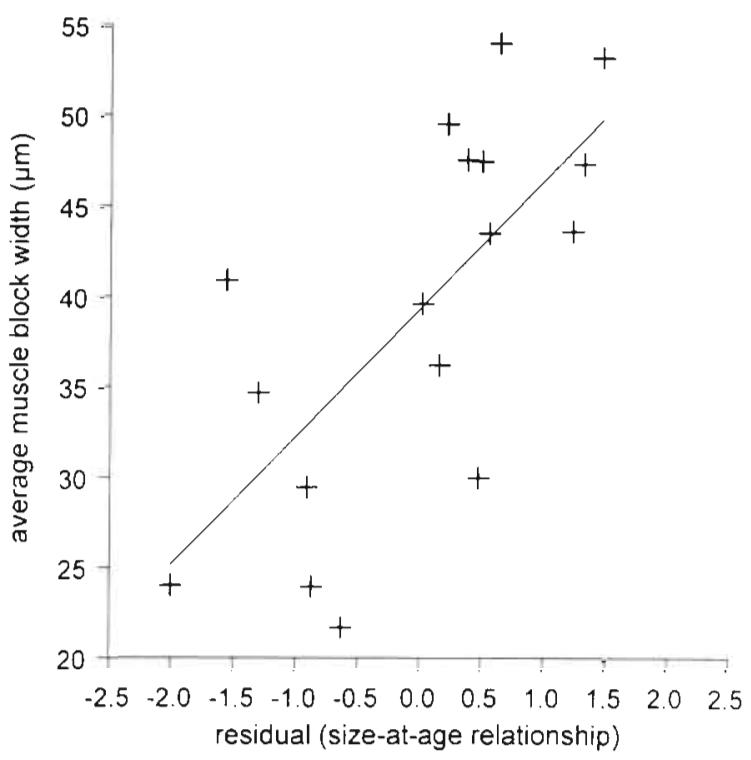

Fig. 5. Sepioteuthis lessoniana. Relationship between average muscle block width $(\mu \mathrm{m})$ of juvenile individuals and the residuals from the size-at-age relationship. The linear regression line is given

\section{DISCUSSION}

Growth rates of individuals of Sepioteuthis lessoniana were highly variable, demonstrating the plastic growth responses typical of squid (Jackson 1994). Sexspecific growth patterns and sexual maturity stage may be sources of intra-species plasticity in growth rates of squid (Jackson \& Choat 1992, Brodziak \& Macy 1996). However, there was no evidence of sex-or maturity-specific growth for individuals of $S$. lessoniana, as males and females and immature and mature individuals demonstrated very similar growth.

As the focus of this study was to determine if differences in size-at-age between individuals were reflected at lower levels of biological organization, other possible factors which may be causing this plasticity in growth in individuals of Sepioteuthis lessoniana were not examined. However, as temperature can have a marked effect on the growth rates of squids (Jackson \& Choat 1992, Jackson et al. 1997), it is likely that the variation in size-at-age is largely due to seasonal differences in temperatures experienced by individuals and perhaps other factors, such as food availability.

The plastic growth response was not reflected at the biochemical level of organisation. There were weak relationships between the growth rate and proximal composition of both mantle muscle tissue and the digestive gland; however, no more than $24 \%$ of the variability in growth rates was explained at the proximal level. A strong positive relationship between muscle block size and growth rate for both juveniles and adults suggests 
that muscle block size may be a key element to understanding the variability in squid growth rates.

Despite their smaller body mass, juvenile Sepioteuthis lessoniana individuals had greater concentrations of lipid in the muscle tissue. It is possible that there may be an emphasis on storing lipid in the muscle of juveniles of $S$. lessoniana. Juvenile squid, like larval fish, are thought to experience periods of low food availability (Vecchione 1987); therefore storing energy reserves may be crucial to survival. However, high lipid levels are not typical for juvenile cephalopods (e.g. cranchiid squid Galiteuthis glacialis Piatkowski \& Hagen 1994). Alternatively, the predominance of small muscle fibres in the mantle muscle tissue of juveniles may result in a higher relative proportion of lipid present as structural components when compared to adults.

The weak correlations between growth and proximal composition evident in individuals of Sepioteuthis lessoniana are similar to observations made for the rainbow trout Salmo gairdneri (Weatherley \& Gill 1983). In both the whole individual and in tissues, levels of protein, water and lipid in S. gairdneri remained relatively constant in fish of the same age group but with different growth rates. It would appear that in both fish and squid, differences in body constituents between individuals are not related to individual growth rate. This may result from whole animal growth and changes in biochemical composition occurring on different time scales, despite biochemical make-up being the lowest level of growth (Weatherley 1990). Whole animal growth is most likely to change over longer time scales and is influenced by environmental factors, population densities and to some extent genetic programming (Weatherley \& Gill 1987). It is possible that body constituents remain relatively constant despite differences in the growth rates of individuals, so as not to cause severe interruptions to tissue and organ structure (Weatherley \& Gill 1987, Weatherley 1990).

The high levels of carbohydrate $1.86 \%$ wet weight [wwt]) present in the digestive gland of individuals of Sepioteuthis lessoniana compared to those of the muscle tissue of this $(0.47 \%$ wwt) and other squids (e.g. Loligo opalescens $0.17 \%$ wwt, Giese 1969; Illex argentinus 1.16 to $1.32 \%$ wwt, Clarke et al. 1994) suggest that the role of the gland with respect to carbohydrate needs to be examined. The presence of carbohydrate vacuoles in the epithelium of the digestive gland of the loliginid squids $L$. vulgaris and $L$. forbesi suggests that carbohydrate may be stored in the gland (Boucher-Rodoni \& Boucaud-Camou 1987). Similar vacuoles have not been detected in the digestive gland of S. lessoniana based on histo-chemical tests on a wide size range of squid (Semmens unpubl. data). However, the possibility of carbohydrate storage in the digestive gland of individuals of $S$. lessoniana still needs to be further investigated.

Despite the digestive gland of individuals of Sepioteuthis lessoniana containing 4 times as much lipid as that of the muscle, Semmens (1998) has demonstrated that the majority of this lipid is dietary excess that perhaps cannot be metabolised and is excreted by the gland rather than providing an energy store.

Due to its large mass, an understanding of growth requires an understanding of the mechanisms of muscle tissue increase (Weatherley \& Gill 1987, Moltschaniwskyj 1994, Pecl \& Moltschaniwskyj 1997). An examination of growth in the loliginid Photololigo sp. 3 (see Yeatman \& Benzie 1994) and the small tropical sepioid Idiosepius pygmaeus has shown that muscle growth, like that of teleosts, occurs via generation of new fibres (hyperplasia) and an increase in the size of existing fibres (hypertrophy) (Moltschaniwskyj 1994, Pecl \& Moltschaniwskyj 1997). However, unlike the muscle growth of fish, these cephalopods have continued hyperplasic growth throughout the entire life span, providing a mechanism by which the linear growth exhibited by these species and the continuous growth exhibited by cephalopods in general is achieved (Moltschaniwskyj 1994, Pecl \& Moltschaniwskyj 1997), Growth of Photololigosp. 3 occurs via the production of new muscle fibres and an increase in the size of existing fibres in muscle blocks throughout the life span, with muscle blocks increasing in size as individuals grow larger (Moltschaniwskyj 1994). This also occurs in individuals of Sepioteuthis lessoniana, with adults having bigger muscle blocks than juveniles. However, there is also a strong positive relationship between the size of muscle blocks and size-at-age of individuals for both juveniles and adults. This suggests that larger muscle blocks are not only related to body size, but also to individual growth rate. As the relative balance of hyperplasic and hypertrophic processes contributing to muscle growth appears constant throughout the life span of Photololigosp. 3 (Moltschaniwskyj 1994), an increase in the rates of both processes will be expressed in the size of muscle blocks (Moltschaniwskyj 1994). This may explain why there was no relationship between individual size-at-age and average fibre size.

Perhaps not surprisingly, the nature of the growth and structure of mantle muscle tissue in squids appears to be closely linked to the plastic growth response of these animals. This study demonstrates a clear relationship between mantle muscle structure and muscle growth and the size-at-age of individuals of Sepioteuthis lessoniana. A clearer picture of this relationship in squid may be gained by examining mantle muscle tissue growth and structure and the rates and nature of muscle protein synthesis under set temperature and nutritional regimes. 
The biochemical composition of organs and tissues was not directly related to the variable growth responses of squid. Measuring the rate of change in the concentrations of protein, lipid and carbohydrate may prove more useful in future examinations of squid growth, rather than just measuring levels of these constituents.

Acknowledgements. We thank R. Thomas and G. Pecl for ageing individuals and $G$. Pecl also for her constructive comments on drafts of this manuscript. This work was supported by a Merit Research Grant from James Cook University (JCU) and was carried out while J.M.S. was on the Monkman Scholarship at JCU. This is contribution no. 8 of the Marine Invertebrate Group at JCU.

\section{LITERATURE CITED}

Alford RA, Jackson GD (1993) Do cephalopods and larvae of other taxa grow asymptotically? Am Vat 141(5):717-728

Arkhipkin A, Nekludova N (1993) Age, growth and maturation of the loliginid squids Alloteuthis africana and $A$. subulata on the West African Shelf. J Mar Biol Assoc UK 73:949-961

Bigelow KA (1994) Age and growth of the oceanic squid Onychoteuthis borealijaponica in the North Pacific. Fish Bull 92:13-25

Boucher-Rodoni R, Boucaud-Camou E (1987) Fine structure and absorption of ferritin in the digestive organs of Loligo vulgaris and $L$. forbesi (Cephalopoda, Teuthoidea). J Morphol 193:173-184

Bradford MM (1976) A rapid and sensitive method for the quantification of microgram quantities of protein utilizing the principle of protein-dye binding. Anal Biochem 72 : $248-254$

Brodziak JKT, Macy WK (1996) Growth of long-finned squid, Loligo pealei, in the northwest Atlantic. Fish Bull 94: $212-236$

Clarke A, Rodhouse PG, Gore DJ (1994) Biochemical composition in relation to the energetics of growth and sexual maturation in the ommastrephid squid Illex argentinus. Phil Trans R Soc Lond B 344:201-212

Dawe EG (1988) Length-weight relationships for short finned squid in Newfoundland and the effect of diet on condition and growth. Trans Am Fish Soc 117:591-599

Ferron A, Leggett WC (1994) An appraisal of condition measures for marine fish larvae. Adv Mar Biol 30:217-303

Giese AC (1969) A new approach to the biochemical composition of the mollusc body. Oceanogr Mar Biol Annu Rev $7: 175-229$

Jackson GD (1990) Age and growth of the tropical nearshore loliginid squid Sepioteuthis lessoniana determined from statolith growth-ring analysis. Fish Bull 88:113-118

Jackson GD (1994) Application and future potential of statolith increment analysis in squids and sepioids. Can J Fish Aquat Sci 51:2612-2625

Jackson GD, Choat JH (1992) Growth in tropical cephalopods: an analysis based on statolith microstructure. Can J Fish Aquat Sci 49:218-228

Jackson GD, Yeatman J (1996) Variation in size and age at maturity in Photololigo (Mollusca: Cephalopoda) from the northwest shelf of Australia. Fish Bull 94:59-65

Editorial responsibility: Daniel Alongi (Contributing Editor), Townsville, Queensland, Australia
Jackson GD, Forsythe JW, Hixon RF, Hanlon RT (1997) Age, growth, and maturation of Lolliguncula brevis (Cephalopoda: Loliginidae) in the northwestern Gulf of Mexico with a comparison of length-frequency versus statolith age analysis. Can J Fish Aquat Sci 54:2907-2919

Lipinski MR (1979) Universal maturity scale for the commercially important squids (Cephalopoda: Teuthoidea). The results of maturity classification of the Illex illecebrosus (LeSueur 1821) populations for the years 1973-1977. ICNAF Res Doc 79/2/38 Serial 5364

Mann R, Gallager SM (1985) Physiological and biochemical energetics of larvae of Teredo navalis L. and Namkia gouldi (Bartsch) (Bivalve: Teredinidae). J Exp Mar Biol Ecol 85:211-228

Moltschaniwskyj NA (1994) Muscle tissue growth and muscle fibre dynamics in the tropical loliginid squid Photololigo sp. (Cephalopoda: Loliginidae). Can J Fish Aquat Sci 51:830-835

Moltschaniwskyj NA, Martínez P (1998) Effect of temperature and food levels on the growth and condition of juvenile Sepia elliptica (Hoyle 1885): an experimental approach. J Exp Mar Biol Ecol 229:289-302

Natsukari Y, Nakanose T, Oda K (1988) Age and growth of loliginid squid Photololigo edulis Hoyle 1885. J Exp Mar Biol Ecol 116:177-190

Nigmatullin CM, Arkhipkin AI, Sabirov RM (1995) Age, growth and reproductive biology of diamond-shaped squid Thysanoteuthis rhombus (Oegopsida: Thysanoteuthidae). Mar Ecol Prog Ser 124:73-87

O'Dor RK, Durward RD, Vessey E, Amaratunga T (1980) Feeding and growth in captive squid, Illex illecebrosus, and the influence of food availability on growth in the natural population. Int Comm Northwest Atl Fish Sel Pap 6:15-21

Pecl GT, Moltschaniwskyj NA (1997) Changes in muscle structure associated with somatic growth in Idiosepius pygmaeus, a small tropical cephalopod. J Zool Lond 242:751-764

Piatkowski U, Hagen W (1994) Distribution and lipid composition of early life stages of the cranchiid squid Galiteuthis glacialis (Chun) in the Weddell Sea, Antarctica. Antarctic Sci 6(2):235-239

Preuss T, Lebaric ZN, Gilly WF (1997) Post-hatching development of circular mantle muscles in the squid Loligo opalescens. Biol Bull 192:375-387

Rodhouse PG, Hatfield EMC (1990) Dynamics of growth and maturation in the cephalopod Illex argentinus de Castellanos, 1960 (Teuthoidea: Ommastrephidae). Phil Trans R Soc Lond B 329:229-241

Semmens JM (1998) An examination of the role of the digestive gland of two loliginid squids, with respect to lipid: storage or excretion? Proc R Soc Lond B 265:1685-1690

vecchione $M$ (1987) Juvenile ecology. In: Boyle PR (ed) Cephalopod life cycles, Vol II. Comparative reviews. Academic Press, New York, p 61-84

Weatherley AH (1990) Approaches to understanding fish growth. Trans Am Fish Soc 119:662-672

Weatherley AH, Gill HS (1983) Protein, lipid, water and caloric contents of immature rainbow trout, Salmo gairdneri Richardson, growing at different rates. J Fish Biol 23:653-673

Weatherley AH, Gill HS (1987) The biology of fish growth. Academic Press, London

Yeatman J, Benzie JAH (1994) Genetic structure and distribution of Photololigo spp. in Australia. Mar Biol 118:79-87

Submitted: March 1, 1999; Accepted: August 20, 1999

Proofs received from author(s): February 8, 2000 